\title{
RELASI ISLAM DAN BUDAYA DALAM WACANA ISLAM NUSANTARA
}

\author{
Muh. Panji Maulana \\ IAIN Syekh Nurjati Cirebon
}

\begin{abstract}
Abstrak: Wacana Islam Nusantara mulai marak diperbincangkan kembali terutama pada saat istilah tersebut diusung oleh PBNU sebagai tema Muktamarnya yang ke-33 pada tanggal 1-5 Agustus 2015 di Jombang Jawa Timur. Islam Nusantara sendiri mengungkapkan dirinya sebagai Islam yang akomodatif terhadap budaya lokal. Adanya klaim tersebut memunculkan anggapan bahwa munculnya wacana Islam Nusantara dipandang sebagai peneguhan terhadap Islam yang bercorak sinkretis. Tulisan ini berusaha mengkaji mengenai relasi antara Islam dan budaya dalam wacana Islam Nusantara. Dari data yang diperoleh, relasi antara Islam dan budaya dalam wacana Islam Nusantara diidentifikasi sebagai penerapan Islam yang berpijak pada pribumisasi. Pola tersebut dapat dilihat misalnya dari penerapan Islamnya yang kontekstual, akomodatif terhadap budaya dengan mengembangkan aplikasi nash yang disesuaikan dengan kondisi sosial. Penerapan Islam model ini dilakukan juga hanya sebatas dalam tataran muamalah sehingga membedakanya dengan pola negosiasi atau sinkretisasi.
\end{abstract}

Kata Kunci: Islam Nusantara, Islam,Budaya, dan Pribumisasi.

\section{A. Pendahuluan}

Salah satu corak Islam yang mengkampanyekan diri sebagai Islam yang akomodatif terhadap budaya ialah kelompok yang mengususng Islam Nusantara. Bagi para pengusungnya, istilah Islam Nusantara di kaitkan dengan Islam yang akomodatif terhadap budaya, Islam yang merangkul budaya dan tidak memusuhi budaya ${ }^{1}$. Islam Nusantara merupakan sebuah pemahaman keislaman yang bergumul, berdialog dan menyatu dengan kebudayaan Nusantara, dengan melalui proses seleksi, akulturasi dan adaptasi ${ }^{2}$.

${ }^{1}$ Hayder Affan. "Polemik Dibalik Istilah Islam Nusantara". BBC Indonesia. 15 Juni 2015. Diunduh dari www.libforall.org pada tanggal 8 April 2016

2 Abdul Munim DZ dalam Zainul Milal Bizawie. Masterpiece Islam Nusantara; Sanad dan Jejaring Ulama-Santri (1830-1945). Tangerang:Pustaka Compas. 2016. Hal. 3 
Istilah dan diskursus mengenai Islam Nusantara ini mulai marak diwacanakan terutama semenjak organisasi masyarakat (ormas) Nahdlatul Ulama (NU) menetapkan istilah tersebut sebagai tema muktamarnya yang ke-33 yang diselenggarakan di Jombang pada tahun 2015 yang lalu. Gagasan Islam Nusantara ini juga merupakan salah satu agenda organisasi tersebut dalam rangka membumikan Islam yang toleran, ramah, dan akomodatif dengan karakter kearifan lokal, tradisi, dan budaya dengan berlandaskan ideologi Ahl al-sunnah wa al-jama'ah yang berwatak tawazzum, tawassuth, tasamuh, dan itidal. $^{3}$

Semenjak kemunculannya, gagasan Islam Nusantara mendapat tanggapan yang beragam, ada yang menolak, ada yang menerima, dan ada yang bersikap kritis ${ }^{4}$. Bahkan beberapa tanggapan yang skeptis cenderung menilai Islam Nusantara sebagai corak berislam yang primordial, mengkotak-kotakan agama Islam yang universal, bahkan dianggap sebagai konspirasi dari Barat dan Zionis. ${ }^{5}$ Islam Nusantara juga dianggap sebagai usaha untuk meneguhkan corak Islam yang sinkretis.

Adanya klaim atau stigma negatif terutama yang berkaitan dengan sinkretisasi Islam tersebut merupakan hal yang wajar. Hal ini terutama apabila dikaitkan dengan pengakomodasiannya terhadap budaya, sehingga memunculkan penilaian seperti itu. Akan tetapi, penilaian tersebut kiranya perlu untuk ditinjau kembali, mengingat pengakomodasian Islam terhadap budaya sendiri memiliki berbagai ragam macam corak, dan diantaranya tidak sampai memunculkan corak yang sinkretis. Untuk mengetahui hal itu tentunya diperlukan upaya yang lebih mendalam dalam mengkaji wacana Islam Nusantara tersebut dengan mengkajinya baik dalam tataran konsepsi maupun dalam konteks kemunculanya secara historis, sosial dan filosofis, sehingga akan didapatkan gamabaran secara lebih komprehensif dan holistis.

\section{B. Metodologi}

Tulisan ini merupakan penelitian wacana, sehingga pendekatan yang dipakai ialah pendekatan kualitatif. Secara spesifik tulisan ini dimaksudkan untuk mengurai mengenai relasi Islam dan budaya dalam wacana Islam Nusantara. Sebagai batasan tulisan ini di fokuskan pada wacana Islam Nusantara yang muncul pada momen Muktamar NU ke-33 di Jombang-Jawa

\footnotetext{
${ }^{3}$ A. Mustofa Haroen. Meneguhkan Islam Nusantara: Biografi Pemikiran \& Kiprah Kebangsaan Prof. Dr. Said Aqil Siroj, MA. Jakarta: Khalista. 2015. Hal. 112

${ }^{4}$ Pizaro N. Tauhidin. Islam Nusantara dan Tantangan Persatuan Ahlussunnah. Hal. 6. Diambil dari ebook Islam Nusantara: Islamisasi Nusantara atau Menusantarakan Islam?. Terbitan 1 Agustus. Diunduh dari www.hidayatullah,com pada tanggal 08 April 2016

${ }^{5}$ Ahmad Sahal, Munawir Aziz. Islam Nusantara: Dari Ushul Fiqh Hingga Konsep Historis. Bandung: Mizan. 2015. Hal. 16
} 
Timur pada tahun 2015. Adapun sumber data yang dipakai ialah buku-buku yang membahas mengenai wacana Islam Nusantara terbitan tahun 20152016 dan sumber tulisan dari website resmi NU.

Untuk mendapatkan kesimpulan dari relasi Islam dan budaya tersebut kajian ini akan memakai analisis wacana kritis Norman Fairclough dan memakai pendapat dari Djoko Surjo, dkk. mengenai tipologi relasi Islam dan budaya. Dengan analisis wacana kritis maka wacana Islam Nusantara akan di kaji dari berbagai aspek, yakni dari aspek teks, konteks produksi wacana, dan konteks sosio-historis dan kultural yang melatar belakangi kemunculan wacana tersebut. Langkah selanjutnya ialah hasil dari analisis wacana kritis ini akan di analisis dengan kerangka teori mengenai relasi Islam dan budaya menurut Djoko Surjo, dkk.

\section{Tipologi Relasi Islam dan Budaya}

Menurut Surdjo, dkk. dalam Hefni ${ }^{6}$, terdapat tiga varian terkait dengan dialektika antara Islam dan budaya, yaitu islamisasi atau konflik, pribumisasi, dan negosiasi.

Pola islamisasi atau konflik, pola ini mengandaikan adanya sikap yang saling bertahan antara agama dan budaya dalam pergumulan antara keduanya. Hal ini akan terwujud dari pola yang relative "menyimpang" yang dilakukan satu diantara keduanya. ${ }^{7}$

Pribumisasi dalam hal ini diartikan sebagai penyesuaian Islam dengan tradisi lokal dimana ia disebarkan. dalam pribumisasi Islam tergambar bagaimana Islam sebagai ajaran normativ yang berasal dari Tuhan diakomodasikan ke dalam kebudayaan yang berasal dari manusia tanpa kehilangan identitasnya masing-masing. Pribumisasi Islam dengan demikian menjadikan agama dan budaya tidak saling mengalahkan melainkan berwujud dalam pola nalar keagamaan yang tidak lagi mengambil bentuk yang autentik dari agama, serta berusaha mempertemukan jembatan yang sclama ini memisahkan antara agama dan budaya ${ }^{8}$.

Sedangkan pola negosiasi dimaksudkan sebagai dialektika antara Islam dan budaya yang dicirikan dengan adanya proses saling mengubah antara keduanya yang pada batas-batas tertentu, berujung pada perubahan bentuk

${ }^{6}$ Mohammad Hefni. Islam Madura: Resistensi dan Adaptasi Tokoh Adat atas Penetrasi Kiai Madura. Analisis, Volume XIII, Nomor 1, Juni 2013. Hal. 2. Atau lihat rujukan langsung, Joko Suryo, et al., Agama dan Perubahan Sosial; Studi tentang Hubungan antara Islam, Masyarakat dan Struktur Sosial-Politik Indonesia. Yogyakarta: Pusat Antar Universitas-Studi Sosial UGM. 1993

${ }^{7}$ Ibid.

${ }^{8} 8$ Mangun Budiyanto, dkk. "Pergulatan Agama dan Budaya; Pola Hubungan Islam dan Budaya Lokal di Masyarakat Tutup Ngisor, Lereng Merapi, Magelang Jawa Tengah". Jurnal Penelitian Agama. Vol. XVIII. No. 3. September 2008. Hal. 652. Diunduh dari http://digilib.uin-suka.ac.id/ pada tanggal 23 Mei 2016 
masing-masing tradisi tersebut ${ }^{9}$, sehingga pada pola ini memunculkan corak Islam yang cenderung sinkretis.

\section{Wacana Islam Nusantara}

Wacana Islam Nusantara mulai ramai diperbincangkan secara luas terutama setelah istilah tersebut dipakai dalam tema Muktamar Nahdlatul Ulama (NU) ke 33 yang diselenggarakan di Jombang pada tanggal 1-5 Agustus 2015 yang lalu. Tema yang diusung dalam muktamar tersebut ialah "Meneguhkan Islam Nusantara Untuk Peradaban Dunia dan Indonesia"10. Bahkan sebelum penyelenggaraan muktamar tersebut istilah Islam Nusantara sebenarnya sudah muncul dan diperbincangkan dalam acara yang diselenggarakan oleh ormas itu juga, yakni pada saat penyelenggaraan Musyarwarah Nasional Alim Ulama (MUNAS) Nahdlatul Ulama yang diselenggarakan beberapa bulan sebelumnya di Masjid Istiqlah Jakarta, yakni pada tanggal 14 Juni 2015.

Beberapa pihak yang mengusung wacana Islam Nusantara memberikan pengertian yang beragam mengenai istilah tersebut, misalnya dari ketua umum PBNU sendiri yakni Said Aqil Siraj yang mengartikan Islam Nusantara sebagai gabungan nilai Islam teologis dengan nilai-nilai tradisi lokal, budaya, dan adat istiadat di tanah air. Ia mendakwahkan Islam tersebut sebagai Islam yang merangkul budaya, melestarikan budaya, menghormati budaya, dan tidak memberangus budaya. Lebih lanjut ia juga mengungkapkan Islam Nusantara secara lebih umum sebagai Islam yang memiliki watak yang ramah, anti radikal, inklusif dan toleran".

Adapun Ahmad Baso mendefinisikan Islam Nusantara sebagai cara bermazhab secara qauli dan manhaji dalam ber-istimbath tentang Islam dari dalil-dalilnya yang disesuaikan dengan teritori, wilayah, kondisi alam, dan cara pengamalannya dari penduduk negeri tersebut ${ }^{11}$. Lebih lanjut ia menegaskan bahwa Islam Nusantara adalah,

"Mazhab berpikir yang dilakukan para ulama Nusantara dalam mengamalkan dan menerjemahkan Islam ke dalam bahasabahasa Nusantara untuk memberikan tafsiran keagamaan normatif ke dalam ajaran atau dalil-dalil Islam itu sendiri",12.

Dari beberapa pengertian tersebut, setidaknya dapat dianalisis bahwa istilah Islam Nusantara sesuai dengan tema yang menjadi titik sentral dari

${ }^{9}$ Ibid. Hal. 653

${ }^{10}$ Azyumardi Azra. "Jaringan Ulama Nusantara". dalam Akhmad Sahal, Munawir Aziz. Islam Nusantara; dari Ushul Fiqh Hingga Konsep Historis. Bandung: Mizan. 2015. Hal. 169

11 Ahmad Baso. Islam Nusantara: Ijtihad Jenius, \& IjmaUlama Indonesia. Jakarta:Pustaka Afid. 2015. Hal. 21

${ }^{12}$ Ibid. 
pewacanaannya memiliki keterkaitan dengan aspek budaya. Keterkaitan ini secara spesifik mewujud dalam bentuk akomodasinya terhadap budaya. Konsekwensi lanjutan dari akomodasinyaterhadap budaya tersebut meniscayakan model Islam tersebut untuk menerapkan Islam secara kontekstual dengan wilayah yang menjadi tempat dimana ia berpijak, perwujudan tersebut sekaligus pula memunculkan beberapa sifat daripadanya yakni Islam yang ramah, inklusif, dan toleran.

\section{E. Konteks Praktik Wacana Islam Nusantara}

Sebuah wacana muncul tentunya tidak mungkin tanpa dilandasi konteks yang mendasari kemunculanya. Demikian juga wacana Islam Nusantara yang muncul pada momen muktamar NU yang ke-33 ini. Wacana ini hadir bukan tanpa maksud dan tujuan, dan tentunya kehadirannya pula bukan karena didasari oleh ketidak sengajaan yang bisa muncul secara tibatiba.

Untuk mengurai mengenai maksud-maksud tertentu yang melandasi kemunculan wacana Islam nusantara ini, setidaknya dapat diketahui dengan mengurai atau dengan melihat wacana tersebut dari konteks praktik wacana yang melatar belakanginya. Pembahasan ini melingkupi pembahasan mengenai identitas pengusung wacana tersebut, sekaligus mengidentifikasi ideologi yang mendasari pemikirannya, konteks ini juga dapat diketahui melalui bagaimana wacana tersebut di distribusikan.

Secara eksplisit, para pengusug wacana Islam Nusantara tidak mengatakan bahwa wacana Islam Nusantara hanya miliki orang-orang NU saja. Namun secara gamblang pula dapat dengan mudah diketahui bahwa aktor utama dibalik maraknya wacana tersebut dapat dikatakan ialah hasil dari kontribusi ormas yang satu ini. Hal ini dapat diketahui bahwa dalam kemunculannya, wacana Islam Nusantara secara massif dikaji setelah istilah ini dijadikan sebagai tema dari muktamar ormas NU ini. Bahkan sebelum dijadikan tema muktamar, ormas NU juga sudah aktif mewacanakan istilah Islam Nusantara ini ${ }^{13}$.

Pewacanaan kembali Islam Nusantara melalui muktamar merupakan bukti dari cukup urgennya istilah tersebut bagi agenda ormas ini. Sebagaimana yang diketahui, muktamar merupakan agenda yang cukup penting dalam penyelenggaraan ormas-ormas keagamaan terutama bagi ormas NU yang satu ini. Hal ini karena dalam penyelenggaraan muktamar, di samping dalam pelaksanaanya melibatkan seluruh unsur ormas yang ada

${ }^{13}$ Bila merujuk pada website resmi NU yakni www.nu.or.id pembahasan mengenai Islam Nusantara baik secara konsepsi maupun penelitian secara akademik semakin marak dikaji oleh ormas NU. Meskipun pada masa sebelum muktamar juga diskursus Islam Nusantara juga sudah di bahas dalam forum-forum ilmiah, meskipun sejauh penilaian penulis masih lebih intens dilakukan menjelang momen muktamar NU yang ke-33. 
di berbagai wilayah, juga didalamnya membahas mengenai agenda-agenda yang cukup urgen yang nantinya akan di jadikan agenda besar untuk dikembangkan oleh ormas tersebut.

Beberapa dari pengusung wacana ini juga mengungkapkan secara eksplisit, bahwa NU merupakan pengusung utama sekaligus pemeliharan model Islam Nusantara. Sebagaimana yang di ungkapkan oleh Yusqi dan Anam bahwa,

"Perintis istilah Islam Nusantara adalah organisasi massa Islam terbesar di Indonesia, yaitu Nahdlatul Ulama (NU) melalui para akademisi Pascasarjana STAINU/UNU Jakarta. Meski tentu bukan istilah baru, namun Islam Nusantara secara khusus dikampanyekan oleh organisasi ini dan secara resmi menjadi tema besar Muktamar Ke-33 NU pada 1-5 Agustus 2015, di Jombang, Jawa Timur". ${ }^{14}$

Secara historis, organisasi masyarakat (Ormas) NU didirikan salah satunya untuk menjaga tradisi Islam yang bercorak Aswaja. Hal ini sebagaimana yang tercatat dalam sejarah, berdirinya ini tahun 1926 merupakan suatu respon atas kondisi politik internasional yang terjadi saat itu, bermula dari adanya Sidang Komite Khilafah yang akan di selenggarakan di Arab Saudi, dimana di Negara Arab Saudi kala itu tengah di kuasai oleh penguasa yang berideologikan pemahaman Wahabi yang anti dengan tasawuf dan tradisi bermazhab. Dengan adanya kondisi tersebut beberapa tokoh ulama Indonesia membentuk suatu aliansi delegasi untuk mengirim utusanya ke negara tersebut. aliansi ini dinamakan dengan Komite Hijaz, dengan tujuan untuk meyampaikan aspirasi kaum muslim Indonesia terutama yang berhaluan Aswaja kepada raja Arab Saudi supaya dapat mengizinkan umat Islam Indonesia untuk dapat melakukan aktivitas ibadah haji sesuai dengan tata cara sesuai dengan mazhabnya. Perkumpulan atau komite inilah yang menjadi cikal-bakal organisasi Nahdlatul Ulama ${ }^{15}$.

Ormas Nahdlatul Ulama ini juga di akui merupakan representasi sekaligus salah satu pewaris dari corak keberagamaan yang ada di Indoenesia itu sendiri. Sebagaimana yang diketahui bahwa Islam di Indonesia merupakan Islam bercorak kultural dan tradisional. Kecenderungan tradisional tersebut dimaksudkan sebagai Islam yang menjaga ketersambungan dengan tradisi yang telah ada sebelumnya baik dalam tradisi bermazhab maupun tradisi yang ada dalam masyarakat ${ }^{16}$,

${ }^{14}$ M Isom Yusqi dan Faris Khoirul Anam. Mabadi Asyrah Islam Nusantara. dikutip dari www.nu.or.id yang dilansir pada 01 Agustus 2015, dan dikutip pada tanggal 21 Agustus 2016 pukul 19:00 WIB.

${ }^{15}$ Rumadi. Post-Tradisionalisme Islam: Wacana Intelekualisme dalam Komunitas $N U$. Cirebon:Fahmina Institut. 2008. Hal. 36-37

${ }^{16}$ Ibid. Hal. 30 
sehingga sesuai pula dengan corak Islam Nusantara yang bersifat akomodatif dengan budaya lokal setempat.

Sebagaimana yang telah disinggung pada sub sebelumnya, produksi wacana Islam Nusantara oleh ormas NU ini tentunya tidak lepas dari pemahaman dasar yang mejadi manhaj berpikirnya. Hal ini dapat dimengerti karena NU sendiri merupakan salah satu pewaris dari transmisi Islam yang telah berakar sejak zaman Islamisasi awal-awal sebelumnya yang memiliki ortodoksi yang terangkum dalam manhaj Ahl al-sunnah wa aljama'ah.

Islam Nusantara sebagai perwujudan Islam yang telah ada dan tetap ada sampai hari ini digambarkan sebagai Islam Ahlu al-sunnah wa aljama'ah yang memiliki sifat moderat, toleran, dan akomodatif terhadap budaya. Ideologi Ahlu al-sunnah wa al-jama'ah atau yang biasa disebut dengan Aswaja digambarkan sebagai ideologi yang bersifat tawasuth, tawazun, tasamuh dan itidal. Manifestasi keberagamaan yang berpijak pada ideologi tersebut memunculkan corak beragama yang lebih fleksibel dan inklusif, sehingga dapat berbaur dengan berbagai perbedaan corak beragama baik dalam Islam maupun diluar Islam, dan akomodatif terhadap budaya termasuk didalamnya dalam menerima tradisi lokal dan paham kebangsaan seperti halnya Pancasila ${ }^{17}$.

Merujuk secara ontologis, identitas Aswaja sebenarnya lebih cocok dikategorikan sebagai manhaj berpikir daripada sebagai mazhab. Hal ini karena aswaja sebagai pemahaman berislam mencakup didalamnya berbagai mazhab, baik mazhab kalam, fqih, ataupun tasawuf. Sehingga tidak cocok dikatakan sebagai mazhab ${ }^{18}$. Terkait dengan Aswaja ini, Aqil Siroj mengartikan istilah tersebut secara historis sebagai "orang-orang yang memiliki metode berfikir keagamaan yang mencakup semua aspek kehidupan yang berlandaskan atas dasar-dasar moderasi, menjaga keseimbangan dan toleran"19.

Semangat bermazhab dari Aswaja ini juga tidak saklek pada satu mazhab secara ekslusif. Karena dalam dalam Aswaja secara historis memiliki berbagai pijakan mazhab. Lebih luas lagi apabila merujuk pada apa yang ditunjukan oleh Rasulullah Saw. dengan ungkpanya "ma ana alaihi yauma wa ashhabi", mereka yang mengikuti tradisi Nabi dan para sahabatnya. Sehingga Aswaja dapat diklaim oleh berbagai kelompok Islam

${ }^{17}$ Said Aqil Siroj. "Rekonstruksi Aswaja Sebagai Etika Sosial“, dalam Akhmad Sahal, Munawir Aziz. Hal. 140

${ }^{18}$ Ibid. hal. 140

19 Said Aqil Siroj. Ahlussunnah wal Jamaah: Sebuah Kritik Historis. Jakarta:Paramuda Jakarta. 2008. Hal. 8 
yang mengaku mengikuti Nabi dan sahabatnya" ${ }^{20}$. Namun yang terpenting dari penerapan Aswaja tersebut ialah penerapan ruh inti dari manhaj tersebut yakni dengan menerapkan agama Islam secara moderat, seimbang, tengahtengah dan toleran, sehingga dapat memunculkan wataknya yang rahmatan li al-alamin yang tercermin dalam pemahaman keislaman ala Islam Nsantara tersebut.

\section{F. Konteks Historis dan Sosio-Kultural Wacana Islam Nusantara}

Hadirnya pewacanaan Islam Nusantara, di samping merupakan konsekuensi dari ideologi dan identitas pengusung wacana tersebut, juga merupakan respon atas realitas sosial yang melingkupinya. Hal ini sebagai mana yang telah diuraikan sebelumnya, bahwa ormas NU hadir sebagai penerus dan penjaga kekhasan Islam Aswaja di Indonesia. ia juga hadir sebagai respon atas kondisi perpolitikan dan situasi keagamaan di Arab Saudi waktu itu yang sedang dikuasai oleh penguasa yang memiliki corak berislam puritan dan kurang bersahabat dengan Islam tradisi seperti halnya yang ada di Indoensia.

Hadirnya pewacanaan Islam Nusantara merupakan bentuk dari penegasan-- Islam yang ada di Nusantara atau Indonesia itu sendiri. Penegasan ini didasari terutama oleh corak, manhaj hingga manifestasi budaya keagamaan Islam yang ramah dan damai yang pernah ada di negeri ini. Dengan demikian Islam Nusantara buka----nlah suatu bentuk sekte, atau aliran baru yang yang selama ini dituduhkan pada istilah Islam Nusantara tersebut ${ }^{21}$.

Penegasan Islam yang telah ada dan telah menjadi identitas Islam di Nusantara tersebut bagi para pengagas konsep Islam Nusantara sangatlah signifikan dan urgen. Hal ini karena model berislam yang ada di Nusantara atau Indonesia ini merupakan model berislam yang toleran, moderat, unik dan distingtif bila dibandingkan dengan corak berislam di wilayah atau negara lain ${ }^{22}$. Hal tersebut dapat dilihat misalnya baik dari proses masuknya Islam ke wilayah Nusantara itu sendiri maupun dari penerapan tradisi berislam yang telah berkembang di wilayah tersebut ${ }^{23}$.

Merujuk pada proses awal masuknya, kedatangan Islam di Indonesia dikatakan menggunakan pendekatan kultural, sehingga kedatangan Islam ke Indonesia dilakukan secara damai ${ }^{24}$. Juga kehadiran Islam di Indonesia tidak

${ }^{20}$ M. Mukhsin Jamil, Musnadi, dkk. Nalar Islam Nusantara: Studi Islam ala Muhammadiyah, al-Irsyad, Persis dan NU. Cirebon:Fahmina Institut. 2008. Hal. 353

${ }^{21}$ Erik Purnama Putra. Ketum PBNU: Islam Nusantara Bukan Ajaran Baru. Dikutip dari http://khazanah.republika.co.id/, pada tanggal 30 Juli 2016, pukul 05:49 WIB.

Azyumardi Azra. Islam Nusantara: Islam Indonesia http://www.republika.co.id/ , dikutip pada tanggal 30 Juli 2016, pukul 06:04 WIB.

${ }^{23}$ M. Ishom Yusqi, dkk. Mengenal Konsep Islam Nusantara. Jakarta:Pustaka STAINU. 2015. Hal. 13

${ }^{24}$ Ibid. 
untuk merusak atau menantang tradisi yang ada. Sebaliknya, islam datang untuk memperkaya dan mengislamkan tradisi dan budaya yang ada secara bertahap. ${ }^{25}$ Senada dengan fakta tersebut, el-Mawa juga mengungkapkan bahwa berdasarkan data-data filologis, keislaman orang Nusantara telah mampu memberikan penafsiran ajarannya sesuai dengan konteksnya, sehingga tidak sampai menimbulkan peperangan fisik dan penolakan dari masyarakat ${ }^{26} .1$

Penegasan atas corak Islam yang ada di Indonesia ini dimaksudkan karena, corak berislam yang berlandaskan ideologi Aswaja ini bersifat moderat, inklusif dan toleran, sehingga Islam Nusantara diharapkan mampu mempertahankan persatuan dalam masyarakat majemuk dan NKRI yang demokratis. Dan karakter Islam Nusantara tidaklah homogen karena watak Nusantara itu sendiri cukup pluralis. Dan dari sudut pandang ideologi dan politik kenegaraan, Islam Nusantara selaras dengan Pancasila, dan wawasan kebangsaan $\mathrm{NKRI}^{27}$.

Adanya penegasan corak Islam yang khas Indonesia sebagaimana yang telah di bahas pada sub sebelumnya tentunya bukanlah hal netral begitu saja, tindakan dalam pewacanaan tersebut secara lebih jauh merupakan implikasi sekaligus konsekuensi dari adanya faktor-faktor yang bersifat politis. Hal ini secara lebih konkrit salah satunya di sebabkan karena adanya corak berislam di Indonesia yang kurang ramah, dan toleran terhadap Islam yang berhaluan moderat seperti yang diwakili oleh ormas NU dan Muhammadiyah. Diantara kedua ormas tersebut, tentunya ormas NU yang lebih terdesak dengan adanya berbagai gerakan tersebut, mengingat fakta bahwa dalam tradisi beragama yang dijalankan ormas NU sendiri yang lebih kentara dalam relasinya dengan praktik bermazhab dan tradisi lokal.

Sebagaimana yang marak diwacanakan selama ini, gerakan transnasional merupakan gerakan yang mengusung pada penerapan Islam secara legal-formal. Kecenderungan yang bersifat legal formal tersebut menjadikan gerakan ini lebih mengedepankan penerapan aspek normatifitas Islam atas berbagai manifestasi tradisi dan budaya. Gerakan ini marak terutama pasca bergulirnya era reformasi di Indonesia pada tahun 1998. Ada berbagai jenis dari gerakan Islam ini, namun diantara gerakan tersebut yang cukup

${ }^{25}$ Zainul Milal Bizawie "Islam Nusantara Sebagai Subjek dalam Islamic Studies: Lintas Diskurus dan Metodologis" dalam Akhmad Sahal, Munawir Aziz. Op. Cit. Hal. 240

${ }^{26}$ Mahrus el-Mawa. Teks dan Karakter Islam Nusantara. dikutip dari www.nu.or.id yang dilansir pada 13 April 2015, dan dikutip pada 21 Agustus 2016 pukul 23:00 WIB.

${ }^{27}$ Imam Tolkhah. "Paham Keagamaan di Lembaga Pendidikan Pada Umumnya Islam Nusantara”. Litbang Diklat. Nomor 2 Tahun 2015. Hal. 35 
dominan ialah gerakan Salafi Wahabi, Ikhwanul Muslimin dan Hizbut Tahrir Indonesia ${ }^{28}$.

Hadirnya kelompok gerakan Trans Nasional tersebut menjadikan Islam di Indonesia menjadi lebih radikal. Hal tersebut karena secara ideologis, kaum puritan terutama kelompok salafi Wahabi yang mendasarkan ideologinya pada pemahaman literatur agama secara literalis, sehingga corak beragamanya terkesan kaku, juga sering mengkafirkan dan membidahkan para penganut paham Islam lain terutama kelompok Islam tradisional $^{29}$. Pemahaman secara literal tersebut salah satunya ialah untuk menghindari kompleksitas pemahaman dan praktik hukum, teologi dan tasawuf yang telah tumbuh semenjak masa risalah berakhir ${ }^{30}$, sehingga wajar saja bila kelompok ini menganggap bidah mengenai bermazhab baik pada mazhab fikih terlebih lagi ikut serta dalam kelompok tasawuf atau tarekat.

Sedangkan para Islam politik seperti HTI, mereka lebih menyerang pada ranah pemahaman politik dan kebangsaan. Seperti yang telah diketahui, kelompok ini mencita-citakan untuk mendirikan sistem pemerintahan khilafah kembali, sehingga sering bertentangan dan memunculkan kontestasi dengan kelompok yang kontra dengan ideologi selain khilafah tersebut. Termasuk pula dengan kelompok yang pro terhadap ideologi Pancasila, Nasionalisme, Demokrasi, yang telah menjadi kesepakatan para pendiri bangsa Indonesia yang didalamnya juga mencakup ulama-ulama Indonesia.

Dari adanya situasi tersebut, maka NU terutama sebagai ormas yang berhaluan Islam tradisi dan menganut paham kebangsaan Pancasila merasa terusik sekaligu bertanggungjawab untuk melakukan counter wacana terhadap isu-isu yang di lontarkan oleh gerakan Islam Trans-Nasional tersebut, salah satunya dengan mengusung wacana Islam Nusantara. ${ }^{31}$ Menurut Said Aqil Siroj, bahwa NU tegas menolak ide gerakan Islam yang mudah mengkafirkan orang lain. Kelompok semacam ini tidak sesuai dengan nilai-nilai ahlu sunnah wa al-jamaah. Menurutnya, Wahabi itu hanya sampai pada tingkat Ahlu al-sunnah saja, tetapi tidak wa al-jamaah. ${ }^{32}$

Dalam salah satu bukunya, Bizawie mengungkapkan Salah satu masterpiece Islam Nusantara ialah tegaknya NKRI dan Pancasila. Dalam pandangan Islam Nusantara, Indonesia merupkan dar al-salam dan Pancasila merupakan intisari dari ajaran Ahlu al-sunnah wa al-jamaah.

${ }^{28}$ Abdurrahman Wahid. Ilusi Negara Islam: Ekspansi Gerakan Islam transnasional di Indonesia. Jakarta: The Wahid Institute, bekerjasama dengan Bhinneka Tunggal Ika, Maarif Institute. 2009. Hal. 78

${ }^{29}$ Ibid. Hal. 63

${ }^{30}$ Ibid.

31 "Wacana Islam Nusantara". Litbang Diklat. Nomor 2 Tahun 2015. Hal. 11

${ }^{32}$ A. Mustofa Haroen. Op. Cit. hal. 127 
Karenanya, mempertahankan NKRI dan mengamalkan Pancasila merupakan perwujudan dari upaya umat Islam Indonesia dalam menjalankan syariat Islam. Ia juga mengungkapkan bahwa Pancasila merupakan pengejawantahan dari Islam Nusantara ${ }^{33}$.

\section{G. Konsepsi Islam dalam Wacana Islam Nusantara}

Penyesuaian dengan tempat di mana Islam itu berpijak merupakan poin utama yang menjadi tujuan penerapan Islam Nusantara. Hal ini dikarenakan pembahasan Islam Nusantara berpusat pada upaya pengkontektualisasian Islam dengan lokus yang menjadi tempat dimana ia berpijak. Kata Nusantara dalam persandinganya dengan Islam sendiri sudah menggambarkan sifatnya yang kontekstual tersebut.

Bentuk dari kontekstualisasi Islam tersebut menurut Bizawie dapat dilakukan dengan mewujudkan nilai-nilai Islam melaui bentuk budaya lokal. Dalam tataran praksisnya dapat berupa berbagai cara, antara lain ialah dengan menyusupkan nilai Islami di dalam budaya lokal, dengan mengambil nilai-nilai Islami untuk memperkaya budaya lokal atau dapat juga dengan menyaring budaya agar sesuai dengan nilai-nilai Islam. ${ }^{34}$

Proses tersebut dimungkinkan karena dalam Islam terdapat kaidah fikih al-adah muhakkamah (adat dapat dijadikan sebagai dasar hukum) maupun pengembangan dan pemahaman aplikasi nash. Upaya tersebut semata-mata ditujukan untuk tercapainya maqashid al-syariah (tujuan syariat), yaitu terwujudnya kemaslahatan (maslahah) manusia di dunia dan akhirat. ${ }^{35}$

Dengan demikian, Islam Nusantara memandang Islam bukan hanya dalam tataran normatif saja, namun ia juga mempertimbangakan praktik dan penerapanya secara historis. Pertimbangan secara historis tersebut menjadikan Islam memiliki berbagai ragam manifestasi. Sehingga perwujudan Islam tidaklah tunggal. Termasuk dalam hal ini ialah manifestasi dari tipologi berislam yang di istilahkan dengan Islam Nusantara ${ }^{36}$.

Islam Nusantara membedakan antara ajaran yang normatif yang tak dapat diubah-ubah dan menjadi pegangan pokok, dengan unsur Islam yang dapat dikompromikan dengan realitas (historisitas). Wilayah dimensi normatif ini terletak pada akidah dan doktrin yang berkaitan dengan ubudiyyah. Sedangkan dalam tataran muamalah penerapan Islam dapat

${ }^{33}$ Ibid.

${ }^{34}$ Zainul Milal Bizawie ."Islam Nusantara Sebagai Subjek dalam Islamic Studies: Lintas Diskurus dan Metodologis" dalam Akhmad Sahal, Munawir Aziz. Hal. 243

${ }^{35}$ Ibid. Hal. 243

${ }^{36}$ Zainul Milal Bizawie. "Islam Nusantara Sebagai Subjek dalam Islamic Studies: Lintas Diskurus dan Metodologis" dalam Akhmad Sahal, Munawir Aziz. Hal. 241 
disesuaikan dengan kondisi lingkunganya masing-masing, dimensi inilah yang dianggap sebagai dimensi yang dapat bergumul dengan aspek historis. Dengan pemahaman tersebut sehingga Islam Nusantara dapat dikatakan masih tetap pada koridor keislamannya sekaligus mampu memenuhi kebutuhanya secara sosial-kultural bagi pemeluknya, sehingga dapat dikatakan pula bahwa model berislam ala Islam Nusantara ini merupakan model berislam yang kaffah. ${ }^{37}$

Dengan demikian garapan Islam Nusantara secara lebih kongkrit dapat dipertegas hanya pada tataran al-mutaghayyirat saja. Aspek almutaghayyirat dapat diartikan sebagai ajaran Islam yang memiliki potensi untuk berubah (al-awaid, al-amaliyah) sesuai ketentuan tempat dan zaman, namun untuk dapat menerapkan konsep tersebut tentunya memerlukan metodologi yang memadai. ${ }^{38}$

Dari tata cara penerapan hukum Islam model Islam Nusantara tersebut dapat dilihat bahwa dalam penerapanya, disamping akomodatif terhadap tradisi dan realitas yang aktual, juga dilandasi dengan semangat kemanusiaan, yakni dengan memprioritaskan kemaslahatan bagi umat yang dikenai suatu hukum tersebut.

Hal ini bukanlah sesuatu yang mengherankan, karena bagi pengusung Islam Nusantara selain memiliki nushush al-syariah (sumber hukum) islam juga memiliki maqasidh al-syariah (tujuan syariat), dan mabadi al-syariah (prinsip-prinsip syariat). Salah satu prinsip syariat yang paling utama sebagai ciri khas agama Islam yang menonjol ialah al-wasathiyyah (sikap tengahtengah). ${ }^{39}$ Dan sikap wasathiyyah ini diilhami oleh ideologinya yang berlandaskan Ahl al-sunnah wa al-jamaah.

Dengan adanya pandangan mengenai Islam yang mencakup dimensi normatif dan historis, inklusif, kontekstual dan mengedepankan maslahat dan maqashid al-syariah ini, sehingga Islam Nusantara memandang budaya dan realitas yang ada dalam kehidupan masyarakat sebagai hal yang lumrah dan justru patut di akomodasi keberadaanya. Budaya atau yang dalam terminologi Islam Nusantara sering dikaitkan dengan al-urf, al-adah, almuamalah, dan al-awaid ini merupakan keniscayaan yang ada dalam kehidupan masyarakat.

\section{H. Konsepsi Budaya dalam Wacana Islam Nusantara}

Dengan adanya pandangan mengenai Islam yang mencakup dimensi normatif dan historis, inklusif, kontekstual dan mengedepankan maslahat

${ }^{37}$ Akhmad Sahal. Islam Nusantara adalah Islam Kaffah ala NU. Dikutip dari http://www.nu.or.id/ pada tanggal 10 Agustus 2016 pukul 03:00

${ }^{38}$ Ibid.

${ }^{39}$ Afifudin Muhajir. "meneguhkan Islam Nusantara utuk Peradaban Indonesia dan Duia" dalam Akhmad Sahal, Munawir Aziz. Hal. 65 
dan maqashid al-syariah ini, sehingga Islam Nusantara memandang budaya dan realitas yang ada dalam kehidupan masyarakat sebagai hal yang lumrah dan justru patut di akomodasi keberadaanya ${ }^{40}$. Budaya atau yang dalam terminologi Islam Nusantara sering dikaitkan dengan al-urf, al-adah, almuamalah, dan al-awaid ini merupakan keniscayaan yang ada dalam kehidupan masyarakat.

Dalam pandangan Islam Nusantara, budaya yang ada dalam suatu wilayah seperti halnya Indonesia bukanlah sesuatu yang harus dijauhi, sebagaimana kaum puritan yang khawatir terhadap pendistorsian akan keberislamannya karena perpaduannya dengan berbagai macam manifestasi budaya. Meskipun begitu Islam Nusantara juga tetap selektif dalam memandang budaya ${ }^{41}$. Karena bagaimanapun budaya memiliki beragam corak dan kualitas, ada yang baik (urfun shahih) dan ada juga budaya yang jelek (urfun fasid) ${ }^{42}$.

Dalam mengapresiasi budaya tersebut Islam Nusantara tidak hanya terpaut pada budaya masa lalu dan budaya lokal saja. Namun ia juga megapresiasi budaya modern dan yang akan datang. Apresiasi terhadap budaya lokal ini, misalnya tercermin dalam penerapan Islam yang berbaur dengan budaya lokal seperti acara nujuh bulan atau mitoni, puputan, slametan Juga pada perayaan kegiatan keagamaan seperti peringatan Israk mikraj, maulid nabi, halal bi halal dan sebagainya, sehingga dengan adanya perpaduan tersebut Islam menjadi kian berwarna dan lebih bernuansa ${ }^{43}$.

Sedangkan dalam menerima budaya modern, Islam Nusantara juga sangat tanggap dalam menghadapi isu-isu kebangsaan seperti halnya Nasionalisme, Demokrasi, dan Pancasila. Dalam menerima produk-produk modernisasi tersebut, Islam Nusantara tidak serta-merta lepas dari dasar pijakan keislamannya. Misalnya dengan mengambil keputusan untuk menerima produk-produk tersebut hanya dengan mendasarkan dalil-dalil fisafat secara murni. Islam Nusantara tetap bertaut pada nilai-nilai normatif yang terdapat dalam khazanah fikih dan ushul fiqh secara langsung ${ }^{44}$, sehingga penerapan dan penerimaan Islam Nusantara terhadap budaya atau produk modernisasi tersebut masih masuk dalam koridor syariat.

\footnotetext{
${ }^{40}$ Zainul Milal Bizawie. "Islam Nusantara Sebagai Subjek dalam Islamic Studies: Lintas Diskurus dan Metodologis", Hal. 3

${ }^{41}$ Zainul Milal Bizawie. "Islam Nusantara Sebagai Subjek dalam Islamic Studies: Lintas Diskurus dan Metodologis" dalam Akhmad Sahal, Munawir Aziz. Hal. 240

${ }^{42}$ Ishom Yusqi. MabadiAsyrah Islam Nusantara. dikutip dari www.nu.or.id yang dilansir pada 01 Agustus 2015 dan dikutip pada tanggal 22 Agustus 2016 pukul 02:00 WIB.

${ }^{43}$ Abdul Kholiq. Warna-warni Islam; Potret Keragaman Umat Islam di Seluruh Dunia. Yogyakarta:Qudsi Media. 2012. Hal.140-141

${ }^{44}$ Akhmad Sahal. Islam Nusantara adalah Islam Kaffah ala NU. Dikutip dari http://www.nu.or.id/ pada tanggal 10 Agustus 2016 pukul 03:00
} 


\section{Tipologi Pribumisasi dalam Wacana Islam Nusantara}

Dalam relasinya dengan budaya, Islam Nusantara terkesan lebih berpijak pada konsep pribumisasi Islam. Watak pribumiasi tersebut setidaknya terlihat dalam penerapan nilai-nilai Islam tersebut yang mengakomodasikannya melalui budaya lokal, dengan maksud melakukan upaya kontekstualisasi dengan kehidupan masyarakat setempat. Sehingga mampu memberikan kemaslahatan bagi masyarakat tersebut.

Sebagaimana yang telah diketahui, konsep pribumisasi Islam merupakan konsep pengejawantahan nilai-nilai Islam kedalam budaya lokal. Pribumisasi merupakan pola pencairan karakter Islam sebagai sesuatu yang normatif menjadi sesuatu yang kontekstual. Dalam pribumisasi Islam, Islam sebagai ajaran yang normatif berasal dari Tuhan diakomodasikan ke dalam kebudayaan yang berasal dari manusia tanpa kehilangan identitasnya masing-masing. Pola ini kemudian melahirkan Islam akulturatif dan kontekstual. $^{45}$

Pribumisasi merupakan tipologi yang berusaha menjembatani antara agama dan budaya. Yakni dengan dengan jalan memenuhi kebutuhan akan kontekstualisasi agama dalam lingkup budaya setempat. Sehingga pribumisasi tidak menjadikan agama dan budaya saling mengalahkan. ${ }^{46} \mathrm{Hal}$ ini juga ditampakan dalam konsepsi Islam Nusantara yang memandang antara Islam dan budaya tidak saling bertentangan, namun dapat saling menguatkan secara sinergis. ${ }^{47}$

Penegasan terhadap watak pribumisasi ini juga terlihat pada penegasanya bahwa pegakomodasian nilai-niali tersebut diterapkan hanya sejauh yang berkaitan dengan muamalah dan tidak serta merta mencampur adukan ajaran akidah dan ubudiyyah, sehingga penerapannya masih dalam koridor Islam.

Adanya penegasan akan akomodasi yang dilakukan oleh Islam Nusantara terhadap budaya tersebut sekaligus menjadi penegasian terhadap pola islamisasi yang terkesan kurang akomodatif terhadap budaya, bahkan cenderung menjauhinya (konflik). Penegasian terhadap pola ini juga diperkuat dengan adanya fakta bahwa hadirnya Islam Nusantara merupakan salah satu agenda dalam mengkounter wacana suara-suara yang menyajikan pemahaman Islam yang radikal dan cenderung mengedepankan aspek normatif di Indoensia. Hal ini sebagaimana yang telah dipaparkan sebelumnya bahwa, pemahaman Islam radikan yang diidentikan dengan gerakan Islam Trans Nasional tersebut merupakan gerakan Islam yang lebih menampakan dominasi Islam terhadap tradisi dengan tujuan menerapkan

${ }^{45}$ Ibid. Hal. 2

${ }^{46}$ Ibid.

${ }^{47}$ Zainul Milal Bizawie. "Islam Nusantara Sebagai Subjek dalam Islamic Studies: Lintas Diskurus dan Metodologis" dalam Akhmad Sahal, Munawir Aziz. Hal. 239 
Islam secara total dan legal-formal baik dalam kehidupan sosial, budaya maupun politik.

Adanya fakta pemilahan dan pembatasan dalam relasinya dengan budaya ini juga sekaligus menjadi penegasi terhadap pola negosiasi yang cenderung saling meleburkan masing-masing unsurnya sehingga membentuk unsur yang lain dan memunculkan wataknya yang sinkretis. Menurut Wahid sinkretisme merupakan usaha memadukan teologi atau sistem kepercayaan lama tentang sekian banyak hal yang diyakini sebagai kekuatan ghaib berikut dimensi eskatologisnya dengan Islam yang lalu membentuk panteisme, sehingga dari pandangan tersebut dapat diidentifikasi bahwa sinkretisme atau pola negosiasi tidak identik dengan pola pribumisasi.

Mengenai sinkretisasi ini, seperti halnya konsepsi pribumisasi, Islam Nusantara bukan bermaksud untuk melakukan upaya jawanisasi, sinkretisasi $^{48}$ ataupun nusantaranisasi Islam. Dalam relasinya terhadap budaya, ia tetap menerapkan proses seleksi, akulturasi dan adaptasi, ${ }^{49}$ sehingga Islam Nusantara dengan corak pribumisasinya masih tetap berpegang pada akidah tauhid sebagaimana esensi ajaran Islam yang dibawa oleh Nabi Muhammad Saw. namun tetap akomodatif dan menghargai budaya dan tradisi. ${ }^{50}$

Adanya beberapa kesesuaian antara konsepsi Islam Nusantara dengan konsepsi pribumisasi Islam tersebut diperkuat pula diantaranya oleh pendapat-pendapat dari para pengusung Islam Nusantara tersebut yang secara eksplisit mendasarkan Islam Nusantara pada konsep Pribumisasi Islam. Diantaranya ialah, Said Aqil yang mengatakan bahwa salah satu bangunan epistemik dari Islam Nusantara ialah pribumisasi Islam. Sehingga dari berbagai temuan tersebut dapat relasi antara Islam dan budaya dalam wacana Islam nusantar tersebut memakai pola pribumisasi. Dalam tulisanya, Yusqi juga mengungkapkan bahwa pribumisasi Islam menurut Syaiful Arif, mewadahi dan menaungi apa yang saat ini populer dengan sebutan Islam Nusantara.

\section{J. Kesimpulan}

Relasi antara Islam dan budaya dalam wacana Islam Nusantara dapat dilihat dari pemahamanya terhadap Islam dan budaya. Islam Nusantara memiliki karakteristik Islam yang kontekstual. Pemahaman akan kontekstualisasi Islam ini merupakan sesuatu yang sentral karena poin utama wacana Islam Nusantara ialah sebagai wujud penerapan Islam yang

48 Abdurrahman Wahid. Pergulatan Negara, Agama dan Kebudayaan. Depok:Desantara. 2001. Hal. 119

${ }^{49}$ Zainul Milal Bizawie "Islam Nusantara Sebagai Subjek dalam Islamic Studies: Lintas Diskurus dan Metodologis" dalam Akhmad Sahal, Munawir Aziz.. Hal. 240

${ }^{50}$ Ibid. Hal. 241 
akomodatif terhadap budaya lokal. Pemahaman terhadap kontekstualisasi ini dapat dilihat pada penerapan Islam yang mempertimbangkan historisitas disamping tetap berpegang teguh pada nilai-nilai normatif, sehingga penerapan Islam Nusantara disamping tetap dalam koridor keislamanya sekaligus juga mampu menerapkan kemaslahatan bagi umat.

Bagi Islam Nusantara persentuhan antara Islam dan budaya merupakan sesuatu yang niscaya, bahkan antara Islam dan budaya dapat saling mensinergikan. Budaya membutuhkan Islam agar eksistensinya sesuai dengan nilai-nilai kemanusaiaan, sedangkan Islam membutuhkan budaya karena budaya merupakan ladang penerapan nilai-nilai Islam.

Dari berbagai penggambaran mengenai Islam Nusantara tersebut, Islam Nusantara dapat di identifikasi sebagai pola pribumisasi Islam. Pola tersebut terlihat misalnya dalam hal akomodasi Islam Nusantara terhadap budaya dengan mengembangkan aplikasi nash terhadap kondisi sosial dan kultural. Penerapan pola tersebut juga hanya sebatas dalam tataran dimensi muamalah, sehingga Islam Nusantara tidak sampai terjerumus dalam pola sinkretisasi sekaligus menegasikan pola lainya yang bersifat negosiasi dan Islamisasi. Terlebih kesimpulan akan identifikasi pola pribumisasi dalam wacana Islam Nusantara ini dapat dipertegas dengan adanya pernyataan secara eksplisit dari para pengusung wacan Islam Nusanatara tersebut, bahwa Islam Nusantara merupakan pengembangan dari konsep pribumisasi Islam dari Gus Dur.

\section{DAFTAR PUSTAKA}

Affan, Hayder. Polemik Dibalik Istilah Islam Nusantara. BBC Indonesia. 15 Juni 2015. Di unduh dari www.libforall.org. Pada 08 April 2016

Azra, Azyumardi. "Jaringan Ulama Nusantara". dalam Akhmad Sahal, Munawir Aziz. 2015. Islam Nusantara; dari Ushul Fiqh Hingga Konsep Historis. Bandung: Mizan.

Azra, Azyumardi. Islam Nusantara: Islam Indonesia (2). www.republika.co.id/, dikutip pada tanggal 30 Juli 2016, pukul 06:04 WIB.

Baso, Ahmad. 2015. Islam Nusantara. Jakarta: Pustaka Afid.

Bizawie, Zainul Milal. 2016. Materpiece Islam Nusantara: Sanad dan Jejaring UlamaSantri (1830-1945). Tanggerang:Pustaka Compas.

Bizawie, Zainul Milal. "Islam Nusantara Sebagai Subjek dalam Islamic Studies: Lintas Diskurus dan Metodologis". Dalam Akhmad Sahal, Munawir Aziz. 2015. Islam Nusantara; Dari Ushul Fiqh Hingga Konsep Historis. Bandung: Mizan.

Beritaislami.org. Islam Nusantara dan Sinkretisme. www.beritaislami.org/ dilansir pada 01 Juli 2015. Dikutip pada tanggal 26 Agustus 2016, pukul 13:00 WIB.

Budiyanto, Mangun, Dkk. Pergulatan Agama dan Budaya: Pola Hubungan Islam dan Budaya Lokal di Masyarakat Tutup Ngisor, Lereng Merapi, Magelang Jawa Tengah. Jurnal Penelitian Agama Vol. XVIII. No. 3. September-Desember. 2008.

el-Mawa, Mahrus. 13 April 2015. Teks dan Karakter Islam Nusantara. www.nu.or.id, dikutip pada 21 Agustus 2016 pukul 23:00 WIB. 
Haroen, A. Mustofa. 2015. Meneguhkan Islam Nusantara; Biografi Pemikiran \& Kiprah kebangsaan Prof. Dr. KH. Said Aqil Siroj, MA. Jakarta: Khalista.

Hefni, Mohammad. Islam Madura; Resistensi dan Adaptasi Tokoh Adat atas Penetrasi Kiai Madura. Analisis, Volume XIII, Nomor 1, Juni 2013.

Jamil, M. Mukhsin, Musnadi, dkk. 2008. Nalar Islam Nusantara: Studi Islam ala Muhammadiyah, al-Irsyad, Persis dan NU. Cirebon:Fahmina Institut.

Kholiq, Abdul, dkk. 2001. Warna-Warni Islam: Potret Keragaman Umat islam di Seluruh Dunia. Yogyakarta:Qidsi Media.

Litbang Diklat. "Wacana Islam Nusantara". Litbang Diklat. Nomor 2 Tahun 2015.

Muhajir, Afifudin. "meneguhkan Islam Nusantara utuk Peradaban Indonesia dan Duia" dalam Akhmad Sahal, Munawir Aziz. 2015. Islam Nusantara; Dari Ushul Fiqh Hingga Konsep Historis. Bandung: Mizan.

Putra, Erik Purnama. Ketum PBNU: Islam Nusantara Bukan Ajaran Baru. Dikutip dari http://khazanah.republika.co.id/ , pada tanggal 30 Juli 2016, pukul 05:49 WIB

Rumadi. 2008. Post Tradisionalisme Islam: Wacana Intelektualisme dalam Komunitas $N U$. Cirebon: Fahmina Institut.

Sahal, Akhmad, Munawir Aziz. 2015. Islam Nusantara; Dari Ushul Fiqh Hingga Konsep Historis. Bandung: Mizan.

Sahal, Akhmad. Islam Nusantara adalah Islam Kaffah ala NU. Dikutip dari http://www.nu.or.id/ pada tanggal 10 Agustus 2016 pukul 03:00

Siroj, Said Aqil. "Rekonstruksi Aswaja Sebagai Etika Sosial" dalam Akhmad Sahal, Munawir Aziz. 2015. Islam Nusantara; Dari Ushul Figh Hingga Konsep Historis. Bandung: Mizan.

Siradj, Said Aqil. 2008. Ahlussunnah wal Jamaah: Sebuah Kritik Historis. Jakarta:Paramuda Jakarta.

Tauhidi, Pizaro N. Islam Nusantara dan Tantangan Persatuan Ahlussunah. Hal. 6. Diambil dari ebook Islam Nusantara: Islamisasi Nusantara atau Menusantarakan Islam ?. Diunduh dari Www.hidayatullah,com pada tanggal 08 April 2016

Tolkhah, Imam. "Paham Keagamaan di Lembaga Pendidikan Pada Umumnya Islam Nusantara". Litbang Diklat. Nomor 2 Tahun 2015.

Wahid, Abdurrahman. 2009. Ilusi Negara Islam: Ekspansi gerakan Transnasional di Indoenesia. Jakarta: The Wahid Institut.

Wahid, Abdurrahman Wahid. 2001. Pergulatan Negara, Agama dan Kebudayaan. Depok:Desantara.

Yusuf . Mengislamkan Nusantara. http://madina.or.id/ dilansir pada 26 Agustus 2015. Dikutip pada 19 Agustus 2016, pukul 13:00 WIB.

Yusqi, M Isom dan Faris Khoirul Anam. 01 Agustus 2015. Mabadi Asyrah Islam Nusantara. WwW.nu.or.id, dikutip pada tanggal 21 Agustus 2016 pukul 19:00 WIB.

Yusqi, M. Ishom, dkk. 2015. Mengenal Konsep Islam Nusantara. Jakarta:Pustaka STAINU. 